\title{
Loss of Raf kinase inhibitor protein expression is associated with human papillomavirus 16 infection in anal tumors
}

\author{
LUCAS TADEU BIDINOTTO ${ }^{1,2}$, CARLOS A. R. VÉO ${ }^{1}$, EDGAR ALEMAN LOAIZA ${ }^{1}$, \\ GUILHERME G. RIBEIRO ${ }^{1}$, ADRIANA T. LORENZI ${ }^{1}$, LUCIANA ALBINA REIS ROSA ${ }^{3}$, \\ CRISTINA MENDES DE OLIVEIRA ${ }^{3}$, JOSÉ EDUARDO LEVI ${ }^{3}$, CRISTOVAM SCAPULATEMPO-NETO ${ }^{1,4}$, \\ ADHEMAR LONGATTO-FILHO ${ }^{1,5,6}$ and RUI MANUEL REIS ${ }^{1,5,6}$
}

\begin{abstract}
${ }^{1}$ Molecular Oncology Research Center, Barretos Cancer Hospital, Barretos, SP 14784 400; ${ }^{2}$ Human and Experimental Biology Department, Barretos School of Health Sciences, Dr. Paulo Prata - FACISB, Barretos, SP 14785 002; ${ }^{3}$ Laboratory of Virology, Institute of Tropical Medicine, University of São Paulo, São Paulo, SP 05403 000; ${ }^{4}$ Department of Pathology, Barretos Cancer Hospital, Barretos, SP 14784 400, Brazil; 5 Life and Health Sciences Research Institute, School of Health Sciences, University of Minho, Braga 4704 553; ${ }^{6} 3 B^{\prime}$ 's (Biomaterials, Biodegradables and Biomimetics) Research Group, Portugal Government Associate Laboratory, Braga 4806 909, Portugal
\end{abstract}

Received May 5, 2017; Accepted October 26, 2017

DOI: $10.3892 / 01.2018 .8828$

\begin{abstract}
There has been an increase in the incidence of anal cancer in the past two decades, with squamous cell carcinoma (SCC) being the most frequent histological type identified. Among the risk factors, high-risk human papillomavirus (HPV) infection is the most pervasive. Raf kinase inhibitor protein (RKIP) is expressed in a number of normal human tissues and previous studies have demonstrated the prognostic value of the loss of RKIP expression in several gastrointestinal tumors. Therefore, the present study aimed to evaluate the clinical implications of RKIP expression in a series of neoplastic lesions of the anal canal. The resected tumors of 48 patients [8 high-grade intraepithelial lesions (HSILs), 14 adenocarcinomas and 26 squamous cell carcinomas (SCCs)] were immunohistochemically evaluated for RKIP expression, and the results were correlated with clinicopathological data. The results identified a decreased 5-year overall survival rate in patients with adenocarcinoma (40.8\%) compared with patients with SCC (76.7\%), and a decreased 5-year disease-free survival rate in patients at clinical stages III/IV (37.3 vs. 62.5 and $82.6 \%$ for clinical stages 0 and $\mathrm{I} / \mathrm{II}$, respectively). Low RKIP expression was revealed in $62.5 \%$ of HSILs, $88.5 \%$ of SCCs and $100.0 \%$ of the adenocarcinomas. High RKIP expression was associated with patient ethnicity $(37.5 \%$ in
\end{abstract}

Correspondence to: Dr Rui Manuel Reis, Molecular Oncology Research Center, Barretos Cancer Hospital, 1331 Antenor Duarte Villela, Barretos, SP 14784 400, Brazil

E-mail: ruireis.hcb@gmail.com

Key words: adenocarcinoma, anal cancer, high-grade squamous intra-epithelial lesion, squamous-cell carcinoma, Raf kinase inhibitor protein
non-Caucasians vs. $7.5 \%$ in Caucasians) and patient age (33.3\% in younger patients vs. $0.0 \%$ in older patients). Finally, high RKIP expression was correlated with HPV16 infection status (40\% in $\mathrm{HPV}^{-}$vs. $5.3 \%$ in $\mathrm{HPV}^{+}$patients). A correlation was identified between high RKIP expression and lesions with a generally improved prognosis, such as those diagnosed in younger patients, in situ lesions and lesions of lower clinical grades; there was also a negative correlation between high RKIP expression and HPV16 positivity in patients.

\section{Introduction}

Though considered rare, anal cancer incidence has increased in the last 20 years in the USA (1), with an estimated 8,080 new cases and 1,080 associated mortalities in 2016 (2). The most frequent histological type is squamous cell carcinoma (SCC), responsible for $\sim 95 \%$ of anal tumors (3). The risk factors for anal cancer include human papillomavirus (HPV) infection, immunodeficiency, immunosuppression and tobacco smoking; however being $\mathrm{HPV}^{+}$has been demonstrated to be the most important factor $(4,5)$. Among the distinct HPV types, HPV16 is the most frequently identified in anal SCC (6) and may cause infected cells to progress from intraepithelial neoplasia to high-grade dysplasia, and finally to invasive cancer $(5,7)$. Additionally, an increased prevalence of infection with high-risk HPV (HR-HPV) has been identified in the anal canals of women with HPV-associated pathologies, including cancer of the vulva, vagina and cervix, compared with in women without these HPV-associated pathologies (8).

It has been revealed that HR-HPV infections, particularly with concomitantly elevated expression of the viral gene products E6 and E7, are involved in cell cycle entry and cell proliferation $(9,10)$. E7 protein binds retinoblastoma protein, inducing its degradation and aberrant cell cycle progression by upregulating p21 and p16 (11). E6 protein is involved in several oncogenic events, leading to p53 degradation, nuclear factor 
(NF) $-\kappa \mathrm{B}$ pathway activation under hypoxic conditions, and the upregulation of human telomerase reverse transcriptase, which promotes cell immortalization (11). A previous study identified $\mathrm{NF}-\kappa \mathrm{B}$ as an independent predictor of disease-free survival (DFS) in patients treated with chemotherapy (12).

Rafkinase inhibitorprotein (RKIP) is described as an NF- $\kappa \mathrm{B}$ suppressor (13), an inhibitor of the Raf/mitogen-activated protein kinase/extracellular signal-regulated kinase (ERK) kinase (MEK)/ERK signaling pathway (14), and a regulator of $\mathrm{G}$ protein-coupled receptors (15). RKIP is expressed in several normal human tissues (16), and previous studies have demonstrated the prognostic value of the loss of RKIP expression in various gastrointestinal tumors, including colorectal cancer, gastrointestinal stromal tumors and gastric cancer (17-19). To date, only a limited number of molecular biomarkers have been identified that are able to predict treatment outcomes or response in anal cancer, including HPV infection, p16 protein expression $(20,21)$, and the overexpression of multidrug resistance-associated protein 1, excision repair cross-complementation group 1 and thymidylate synthase (22). KRAS proto-oncogene (KRAS) mutations, which are predictors of patient outcomes (23) in colorectal tumors, were identified at a low frequency in tumors of the anal canal (24). Therefore, the aim of the present study was to evaluate the clinical implications of RKIP expression using immunohistochemistry in a series of invasive lesions (SCCs and adenocarcinomas) and in situ lesions [high-grade squamous intra-epithelial lesions (HSILs)] of the anal canal.

\section{Materials and methods}

Patients and samples. The resected tumors of 48 patients with anal cancer (27 female, 21 male), diagnosed at Barretos Cancer Hospital (Barretos, SP, Brazil) between June 2000 and August 2010, were evaluated and the clinical data are summarized in Table I. The mean age of the patients was 55.9 years (range, 27-86 years). KRAS and BRAF mutation status data were retrieved from our previous study (24), while HPV16 and HPV18 status, and $\beta$-globin, p16, Ki-67, minichromosome maintenance protein complex (MCM) and topoisomerase II $\alpha$ (TOP2A) expression immunohistochemical analyses were retrieved from another previous study (25) and are summarized in Table II. All patients included in the present study provided written informed consent, and the study was approved by the Barretos Cancer Hospital Ethical Committee (Barretos, SP, Brazil) approval under the protocol number 310/2010. The data of all patients alive by December 2012 were censored.

Samples, fixed for $24 \mathrm{~h}$ at room temperature in $10 \%$ buffered formalin and embedded in paraffin blocks, were retrieved from the Department of Pathology of Barretos Cancer Hospital. Subsequently, 5- $\mu$ m-thick sections were placed on histological slides, and hematoxylin and eosin staining (1 min in hematoxylin and $30 \mathrm{sec}$ in eosin at room temperature) was performed to confirm the initial diagnosis using a light microscope (magnification, $\mathrm{x} 400$ ).

Immunohistochemistry. Sections (5- $\mu$ m thick) were subjected to immunohistochemical staining according to the streptavidin-biotin peroxidase method using an
UltraVision Large Volume Detection system Anti-Polyvalent, HRP kit (cat. no. TP-125-HL; LabVision; Thermo Fisher Scientific, Inc., Waltham, MA, USA). Briefly, slides were xylene-deparaffinized and rehydrated in a descending alcohol series $(100,90,70$ and $50 \%$, followed by water), prior to antigen-retrieval for $20 \mathrm{~min}$ at $98^{\circ} \mathrm{C}$ in $10 \mathrm{mM}$ citrate buffer (pH=6.0; Sigma-Aldrich; Merck KGaA, Darmstadt, Germany). Endogenous peroxidase blocking was performed by incubation with hydrogen peroxide (3\% in methanol v/v; Sigma-Aldrich; Merck KGaA) for 10 min at room temperature. Protein blocking was performed for 5 min with UV Block Plus (LabVision; Thermo Fisher Scientific, Inc.). Subsequently, the slides were incubated with a polyclonal primary anti-RKIP antibody (dilution, 1:1,000; cat. no. 07-137; Upstate Biotechnology, Inc., Lake Placid, NY, USA) for $60 \mathrm{~min}$ at room temperature, followed by a secondary biotinylated goat anti-polyvalent antibody (part of the aforementioned kit) for $5 \mathrm{~min}$ at room temperature, after which they were incubated with the streptavidin-peroxidase complex for 5 min (LabVision; Thermo Fisher Scientific, Inc.) at room temperature. Chromogen color development was accomplished with 3,3'-diaminobenzidine (5 min at room temperature) and a Gill-2 hematoxylin counterstain (30 sec at room temperature).

The slides were scored in a blinded manner by one pathologist and one histologist using semi-quantitative criteria, as previously described $(18,26)$ using a light microscope (magnification, $\mathrm{x} 400$ ). The labeling score was determined as the sum of the percentage of positive cells ( 0 , negative; $1,<5 \%$ immunoreactive cells; $2,5-50 \%$ immunoreactive cells; $3,>51 \%$ immunoreactive cells) and the labeling intensity ( 0 , negative; 1, weak; 2, moderate; 3 , strong) in the tumor tissue. RKIP expression was classified as low (scores between 0 and 4) or high (scores 5 and 6). This scoring system was used to compare strongly positive RKIP samples vs. samples with weak/moderate expression. Normal stomach sections expressing RKIP were used as a positive control (19).

Statistical analysis. Analysis of descriptive characteristics was performed to characterize the study population using SPSS statistical software (version 21; IBM Corp., Armonk, NY, USA). Comparisons between groups were performed using Fisher's exact tests and the Kaplan-Meier method was applied to assess survival rates, using a log-rank test to compare the curves. $\mathrm{P}<0.05$ was considered to indicate a statistically significant difference.

\section{Results}

Patient characteristics and survival analysis. Follow-up was performed every 6 months or as necessary (until the point of mortality), with a mean follow-up time of 57.2 months (range, 2.1-158.4 months). From the 48 cases, 8 were diagnosed with HSIL, 14 were diagnosed with adenocarcinomas and 26 were diagnosed with SCC. Log-rank analysis revealed a lower 5-year survival rate for patients with adenocarcinoma (40.8\%), compared with for those with SCC and HSIL (76.7 and 80\%, respectively; $\mathrm{P}=0.0479$; Fig. 1A). No significant difference was observed in the disease-free survival rates between the three tumor types $(\mathrm{P}=0.201$; Fig. 1B). There was no significant difference in the overall survival of patients based on clinical 
Table I. Clinicopathological characteristics of the patients and association with RKIP expression.

\begin{tabular}{|c|c|c|c|c|}
\hline Parameter & $\mathrm{n}$ & Low RKIP, n (\%) & High RKIP, n (\%) & P-value \\
\hline Sex & & & & 0.999 \\
\hline Female & 27 & $24(88.9)$ & $3(11.1)$ & \\
\hline Male & 21 & $18(85.7)$ & $3(14.3)$ & \\
\hline Ethnicity & & & & $0.019^{\mathrm{a}}$ \\
\hline Caucasian & 40 & $37(92.5)$ & $3(7.5)$ & \\
\hline Non-caucasian & 8 & $5(62.5)$ & $3(37.5)$ & \\
\hline Age, years & & & & $0.047^{\mathrm{a}}$ \\
\hline$\leq 46$ & 12 & $8(66.7)$ & $4(33.3)$ & \\
\hline $47-66$ & 24 & $22(91.7)$ & $2(8.3)$ & \\
\hline$\geq 67$ & 12 & $12(100)$ & $0(0.0)$ & \\
\hline Tobacco consumption & & & & 0.665 \\
\hline No & 23 & $19(82.6)$ & $4(17.4)$ & \\
\hline Yes (current or past) & 22 & $20(90.9)$ & $2(9.1)$ & \\
\hline Clinical grade & & & & $0.038^{\mathrm{a}}$ \\
\hline Stage 0 & 6 & $3(50)$ & $3(50)$ & \\
\hline Stages I and II & 24 & $22(91.7)$ & $2(8.3)$ & \\
\hline Stages III and IV & 15 & $14(93.3)$ & $1(6.7)$ & \\
\hline Histological type & & & & $0.037^{\mathrm{a}}$ \\
\hline $\mathrm{SCC}$ & 26 & $23(88.5)$ & $3(11.5)$ & \\
\hline Adenocarcinoma & 14 & $14(100)$ & 0 & \\
\hline HSIL & 8 & $5(62.5)$ & $3(37.5)$ & \\
\hline Clinical response & & & & 0.847 \\
\hline No evidence & 24 & $20(83.3)$ & $4(16.7)$ & \\
\hline Complete & 12 & $11(91.7)$ & $1(8.3)$ & \\
\hline Progression & 7 & $6(85.7)$ & $1(14.3)$ & \\
\hline Status & & & & 0.743 \\
\hline Deceased (by cancer) & 13 & $12(92.3)$ & $1(7.7)$ & \\
\hline Deceased (not by cancer) & 4 & $4(100.0)$ & $0(0.0)$ & \\
\hline Alive without disease & 26 & $21(80.8)$ & $5(19.2)$ & \\
\hline Alive with disease & 5 & $5(100.0)$ & $0(0.0)$ & \\
\hline
\end{tabular}

Where data is missing regarding certain patients, it will not available from the patient medical records. ${ }^{\mathrm{a}} \mathrm{P}<0.05$. SCC, squamous cell carcinoma; HSIL, high-grade squamous intra-epithelial lesions; RKIP, Raf kinase inhibitor protein.

stage (Fig. 1C), but clinical stages III/IV were associated with a poorer disease-free survival rate (a 5-year disease-free survival rate of $37.3 \%$ vs. 62.5 and $82.6 \%$ for clinical stages 0 and I/II, respectively; $\mathrm{P}<0.01$; Fig. 1D). Additionally, older patients ( $\geq 67$ years old) were revealed to experience a poorer 5-year survival rate [41.7 vs. 80.2 and $74.5 \%$ for young-( $\leq 46$ years old) and medium-age patients (47-66 years old), respectively; $\mathrm{P}=0.085$, Fig. $1 \mathrm{E}]$, although there was no significant difference in disease-free survival (Fig. 1F).

Immunohistochemistry findings. Table I presents the clinicopathological features of the patients as associated with RKIP expression. High RKIP expression was associated with non-Caucasian patients (37.5 vs. $7.5 \%$ in Caucasians; $\mathrm{P}=0.019)$ and younger ( $\leq 46$ years old) patients (33.3 vs. $0.0 \%$ of older patients; $\mathrm{P}=0.047)$. Additionally, high RKIP expression was associated with lower tumor clinical stages (50\% in stage 0 vs.
$6.7 \%$ in stages III/IV; $\mathrm{P}=0.038)$. Finally, anal HSILs $(37.5 \%)$ exhibited the greatest percentage of high RKIP expression, followed by anal SCCs $(11.5 \%)$ and adenocarcinomas $(0.0 \%)$ $(\mathrm{P}=0.037$; Table I, Fig. 2). There was no significant difference in overall- or disease-free survival between RKIP-high and RKIP-low expressing patients (Fig. 3A and B). Similarly, following the stratification of patients by tumor type (HSIL and SCC), there was no significant difference in survival based on RKIP expression (Fig. 3C and D). All the patients with adenocarcinoma demonstrated low tumor RKIP expression.

RKIP expression was correlated with HPV16 infection, $K R A S$ and $B R A F$ mutation status, and the expression of $\beta$-globin, p16, Ki-67, MCM and TOP2A, as detected by immunohistochemistry. There were no positive cases of HPV18. All 30 cases that were analyzed for KRAS mutation were wild type, and only 1 case of the 35 analyzed was positive for a $B R A F$ V600E mutation. A decreased percentage of HPV16 ${ }^{+}$ 
Table II. Pathological characteristics of the patients and association with RKIP expression.

\begin{tabular}{lrccc}
\hline Parameter & $\mathrm{n}$ & $\begin{array}{c}\text { Low RKIP } \\
\text { labeling, } \mathrm{n}(\%)\end{array}$ & $\begin{array}{c}\text { High RKIP } \\
\text { labeling, }(\%)\end{array}$ & P-value \\
\hline $\begin{array}{l}\text { HPV16 } \\
\text { Negative }\end{array}$ & 10 & $6(60.0)$ & $4(40.0)$ & $0.013^{\mathrm{b}}$ \\
$\begin{array}{c}\text { Positive } \\
\text { B-globin }\end{array}$ & 38 & $36(94.7)$ & $2(5.3)$ & \\
Weak & 3 & $3(100.0)$ & $0(0.0)$ & 0.999 \\
Strong & 45 & $39(86.7)$ & $6(13.3)$ & \\
p16 & & & & 0.999 \\
Negative & 13 & $11(84.6)$ & $2(15.4)$ & \\
Positive & 34 & $30(88.2)$ & $4(11.8)$ & \\
NA & 1 & NA & NA & 0.637 \\
Ki-67 & & & & \\
$1+2+3+$ & 12 & $10(83.3)$ & $2(16.7)$ & \\
$4+$ & 35 & $31(88.6)$ & $4(11.4)$ & \\
NA & 1 & NA & NA & \\
MCM & & & & 0.999 \\
Negative & 9 & $8(88.9)$ & $1(11.1)$ & \\
Positive & 39 & $34(87.2)$ & $5(12.8)$ & \\
TOP2A & & & & 0.329 \\
$1+2+$ & 32 & $27(90.0)$ & $3(10.0)$ & \\
$3+$ & 12 & $9(75.0)$ & $3(25.0)$ & \\
NA & 4 & NA & NA & \\
\hline
\end{tabular}

Immunohistochemical values acquired from reference $(25) .{ }^{\mathrm{b}} \mathrm{P}<0.05$. NA, not available; HPV, human papillomavirus; MCM, minichromosome maintenance protein complex; TOP2A, topoisomerase II $\alpha$; RKIP, Raf kinase inhibitor protein.

cases were identified with high expression of RKIP, compared with the HPV16- cases (5.3 vs. $40 \%$; $\mathrm{P}=0.013$; Table II), indicating a possible correlation between HPV16 infection and RKIP expression.

\section{Discussion}

A number of previous studies have demonstrated that RKIP expression has prognostic value in several tumor types, including gastric, colorectal and gastrointestinal stromal tumors (17-19). However, other studies have identified a number of molecular distinctions between anal canal tumors and their colorectal counterparts $(24,27)$. Therefore, the present study aimed to evaluate RKIP expression in invasive and in situ tumors of the anal canal, and to correlate findings with the clinicopathological data.

The results of the present study revealed a poorer overall survival rate in patients diagnosed with adenocarcinoma, compared with in those diagnosed with SCC or HSIL. An improved prognosis was expected in patients with HSIL, considering that these in situ lesions are associated with $<30 \%$ recurrence following treatment $(5,28)$. Additionally, the results of the present study demonstrated an improved survival rate
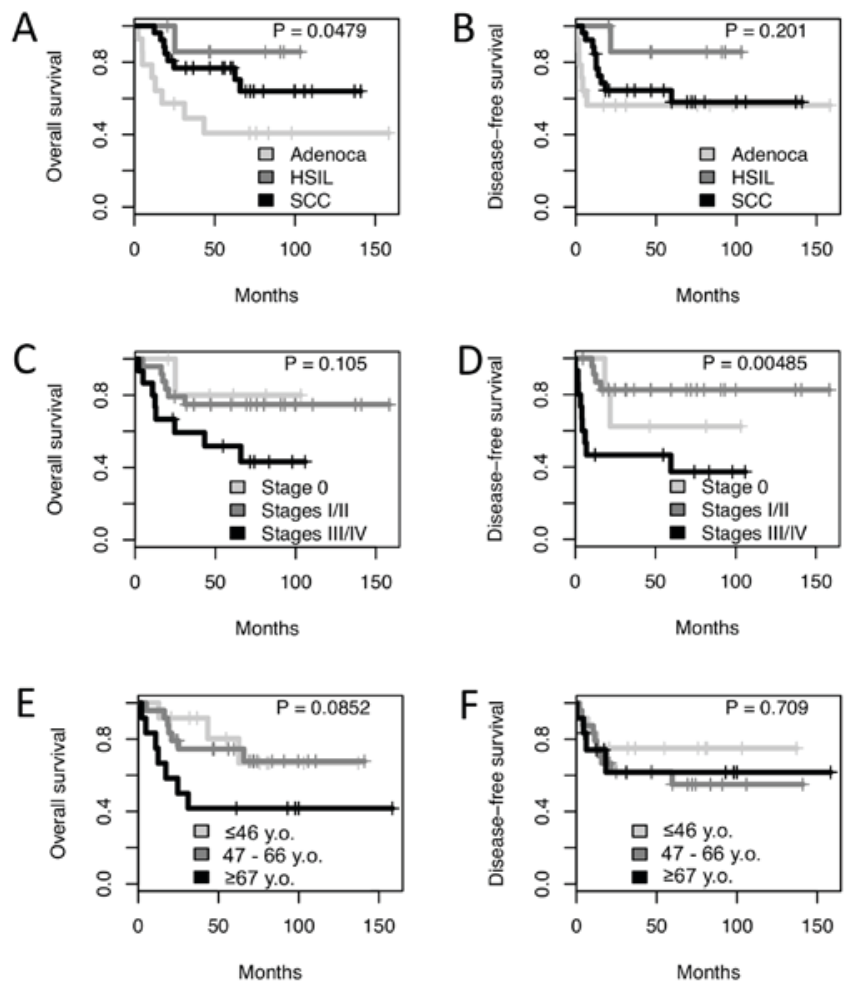

Figure 1. Survival curves based on the various clinicopathological features of patients with anal cancer. (A) Overall survival and (B) disease-free survival of patients with HSIL, adenoca and SCC. (C) Overall survival and (D) disease-free survival based on clinical stage. (E) Overall survival and (F) disease-free survival based on patient age at diagnosis. HSIL, high-grade squamous intra-epithelial lesion; SCC, squamous-cell carcinoma; adenoca, adenocarcinoma; y.o., years old.

\section{A}
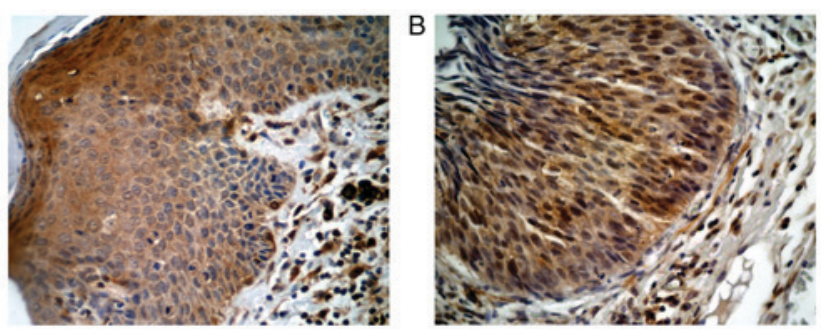

C
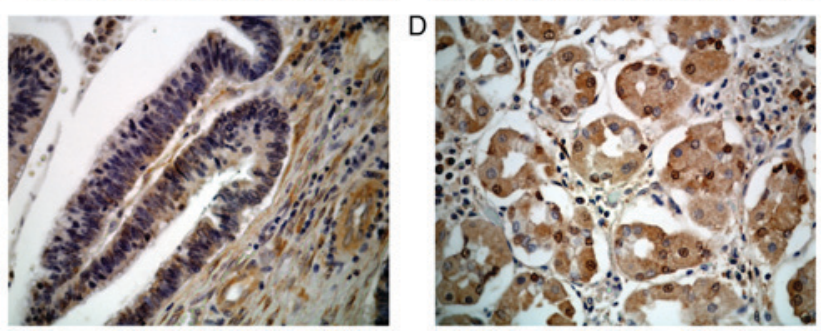

Figure 2. (A-C) Immunohistochemical analysis of RKIP in anal cancer samples. (A) High expression in high-grade squamous intra-epithelial lesions (magnification, x400). (B) High expression in squamous-cell carcinomas (magnification, $x 400)$. (C) Low expression in adenocarcinomas (magnification, $x 400$ ). (D) High expression in normal stomach tissues, which were used as positive controls (magnification, $\mathrm{x} 400$ ). RKIP, Raf kinase inhibitor protein.

in patients with SCC, compared with in patients with adenocarcinoma. This supports the findings of a previous study that compared the overall survival and prognosis of patients with anal adenocarcinoma, SCC and rectal adenocarcinoma, in which the authors demonstrated a poorer overall survival 

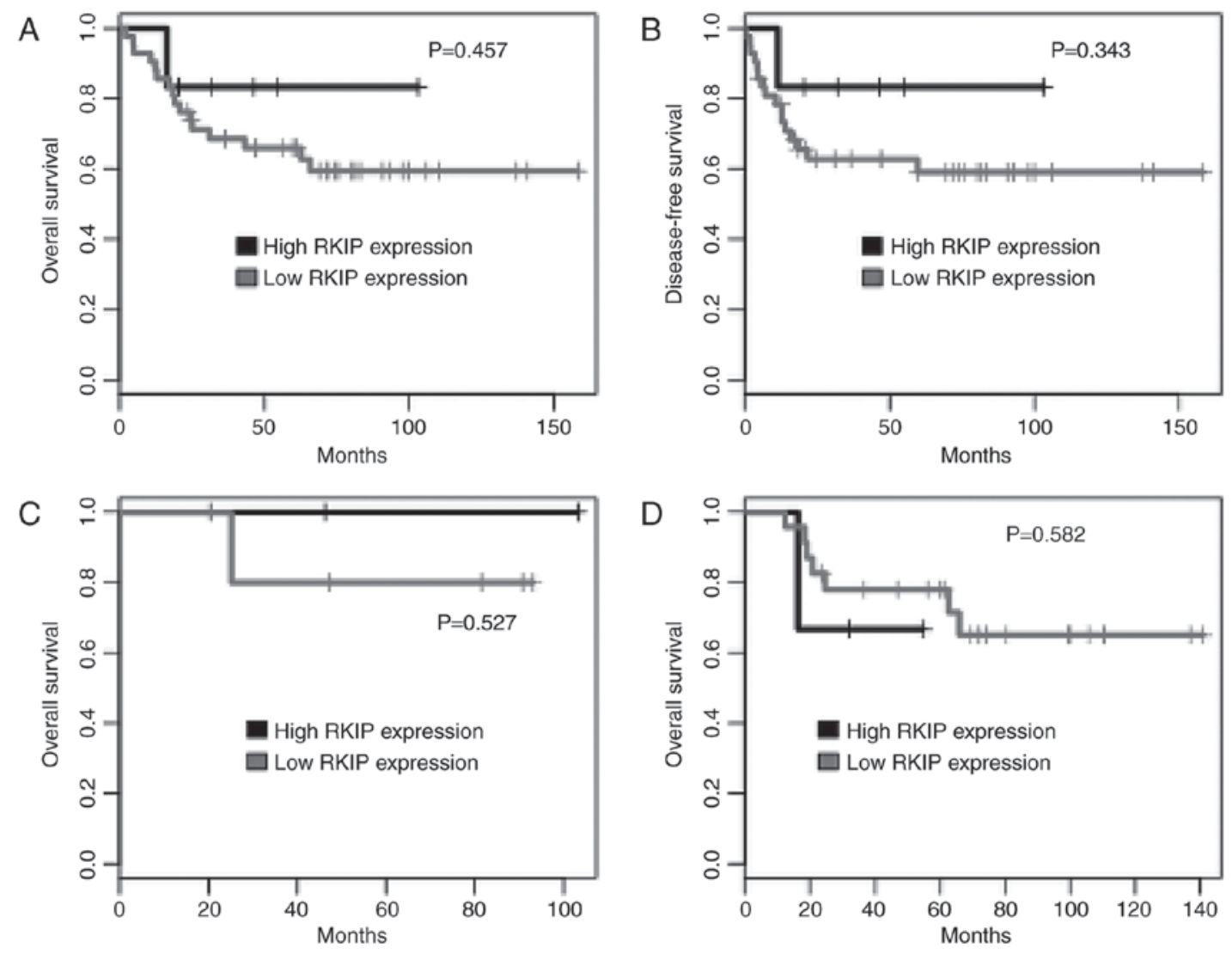

Figure 3. Survival curves based on RKIP expression groups in anal cancer samples. (A) Overall survival and (B) disease-free survival based on the RKIP expression in all samples. (C) Overall survival of patients with HSIL based on RKIP expression. (D) Overall survival of patients with SCC based on RKIP expression. RKIP, Raf kinase inhibitor protein.

rate and prognosis for patients with anal adenocarcinoma (28). This same trend was described by our group in a previous study (24). Furthermore, when considering patient age, the present study identified poorer survival rates in patients $\geq 67$ years old compared with in younger patients ( $\leq 47$ years old), supporting the results presented by a prior study that revealed younger patients experienced improved overall- and disease-free survival rates compared with older patients with anal cancer (29). In addition, the present study did not identify high RKIP expression in the tumors of any older patients.

RKIP is considered a tumor suppressor gene, and its expression may prevent RAF/MEK/ERK signal transduction (30), thus serving a function in the inhibition of cancer development. The present study identified an increased percentage of high RKIP expression in patients with in situ lesions (HSIL) than in patients with invasive lesions (SCC and adenocarcinoma). Notably, an increased percentage of patients at clinical stage 0 exhibited high RKIP expression, compared with patients with higher clinical stages (I/II or III/IV). Considering the patient stratification was dependent on RKIP expression, the lack of receiver operating characteristic analysis may be a limitation of the present study; however, an RKIP scoring system was used according to our previously published studies (26), a method that is widely used for the assessment of immunohistochemistry staining (31), and allowed for inter-study comparisons.

Infection with high-risk HPV (HR-HPV16 and HR-HPV18) is considered the major risk factor for anal cancer development (4). Additionally, a previous study demonstrated that $\mathrm{HPV}^{-} / \mathrm{p}^{-} 6^{-}$patients experienced poorer outcomes compared with $\mathrm{HPV}^{+} / \mathrm{p}^{+} 6^{+}$patients (20). Another study revealed the relevance of p16 expression, reporting an association with improved overall- and disease-free survival rates (6); however, the results of the present study did not identify any correlation between the expression of RKIP and of p16, which may explain the lack of correlation between RKIP expression and survival. In the cohort of the present study, a decreased number proportion of $\mathrm{HPV} 6^{+}$patients exhibited high RKIP protein expression compared with HPV16- patients. Hu et al (32) analyzed RKIP expression via immunohistochemical analysis in normal and cancerous cervical tissues and revealed high RKIP expression in normal tissue, low expression in primary cancer and the lowest (or absent) levels of expression in metastatic disease. Considering that HR-HPV infection is a fundamental step for cervical cancer development $(9,10)$, there may be an inverse association between HR-HPV infection and RKIP expression, as was observed in the present study cohort. However, more studies are required in order to elucidate the molecular basis of this finding.

In conclusion, to the best of our knowledge, this is the first study to investigate RKIP expression levels in a set of anal tumors. The results of the present study demonstrated that high RKIP expression is present in lesions with clinical features that are generally associated with a good prognosis, including lower age at diagnosis, in situ lesions and lesions 
of a lower clinical grade, and that HPV16 infection may affect RKIP expression; a finding that requires further investigation.

\section{Acknowledgements}

The present study was supported by the São Paulo Research Foundation (grant nos. 2010/16795-4 and 2011/08523-7) and MinistryofScience, Technology,InnovationandCommunication (grant no. MCT/FINEP/CT-INFRA-PROINFRA 01/2011).

\section{References}

1. Nelson RA, Levine AM, Bernstein L, Smith DD and Lai LL: Changing patterns of anal canal carcinoma in the United States. J Clin Oncol 31: 1569-1575, 2013.

2. Siegel RL, Miller KD and Jemal A: Cancer statistics, 2016. CA Cancer J Clin 66: 7-30, 2016.

3. Deans GT, McAleer JJ and Spence RA: Malignant anal tumours. Br J Surg 81: 500-508, 1994

4. Bosman FT; World Health Organization and International Agency for Research on Cancer: WHO classification of tumours of the digestive system. IARC Press, Lyon, 2010.

5. Leonard D, Beddy D and Dozois EJ: Neoplasms of anal canal and perianal skin. Clin Colon Rectal Surg 24: 54-63, 2011.

6. Serup-Hansen E, Linnemann D, Skovrider-Ruminski W, Høgdall E, Geertsen PF and Havsteen H: Human papillomavirus genotyping and p16 expression as prognostic factors for patients with American joint committee on cancer stages I to III carcinoma of the anal canal. J Clin Oncol 32: 1812-1817, 2014

7. Burgos J, Curran A, Tallada N, Guelar A, Navarro J, Landolfi S, Villar J, Crespo M, Ribera E and Falcó V: Risk of progression to high-grade anal intraepithelial neoplasia in HIV-infected MSM. AIDS 29: 695-702, 2015.

8. Stier EA, Sebring MC, Mendez AE, Ba FS, Trimble DD and Chiao EY: Prevalence of anal human papillomavirus infection and anal HPV-related disorders in women: A systematic review. Am J Obstet Gynecol 213: 278-309, 2015.

9. Doorbar J: Molecular biology of human papillomavirus infection and cervical cancer. Clin Sci (Lond) 110: 525-541, 2006.

10. Doorbar J: Model systems of human papillomavirus-associated disease. J Pathol 238: 166-179, 2016.

11. Ajiro M and Zheng ZM: Oncogenes and RNA splicing of human tumor viruses. Emerg Microbes Infect 3: e63, 2014.

12. Ajani JA, Wang X, Izzo JG, Crane CH, Eng C, Skibber JM, Das P and Rashid A: Molecular biomarkers correlate with disease-free survival in patients with anal canal carcinoma treated with chemoradiation. Dig Dis Sci 55: 1098-1105, 2010.

13. Yeung KC, Rose DW, Dhillon AS, Yaros D, Gustafsson M, Chatterjee D, McFerran B, Wyche J, Kolch W and Sedivy JM: Raf kinase inhibitor protein interacts with NF-kappaB-inducing kinase and TAK1 and inhibits NF-kappaB activation. Mol Cell Biol 21: 7207-7217, 2001

14. Yeung K, Seitz T, Li S, Janosch P, McFerran B, Kaiser C, Fee F, Katsanakis KD, Rose DW, Mischak H, et al: Suppression of Raf-1 kinase activity and MAP kinase signalling by RKIP. Nature 401: 173-177, 1999.

15. Lorenz K, Lohse MJ and Quitterer U: Protein kinase C switches the Raf kinase inhibitor from Raf-1 to GRK-2. Nature 426 : 574-579, 2003

16. Odabaei G, Chatterjee D, Jazirehi AR, Goodglick L, Yeung K and Bonavida B: Raf-1 kinase inhibitor protein: Structure, function, regulation of cell signaling, and pivotal role in apoptosis. Adv Cancer Res 91: 169-200, 2004.

17. Wang Y, Wang LY, Feng F, Zhao Y, Huang MY, Shao Q, Chen C, Sheng H, Chen DL, Zeng ZL, et al: Effect of Raf kinase inhibitor protein expression on malignant biological behavior and progression of colorectal cancer. Oncol Rep 34: 2106-2114, 2015 .
18. Martinho O, Gouveia A, Silva P, Pimenta A, Reis RM and Lopes JM: Loss of RKIP expression is associated with poor survival in GISTs. Virchows Arch 455: 277-284, 2009.

19. Martinho O, Simões K, Longatto-Filho A, Jacob CE, Zilberstein B, Bresciani C, Gama-Rodrigues J, Cecconello I, Alves V and Reis RM: Absence of RKIP expression is an independent prognostic biomarker for gastric cancer patients. Oncol Rep 29: 690-696, 2013.

20. Mai S, Welzel G, Ottstadt M, Lohr F, Severa S, Prigge ES, Wentzensen N, Trunk MJ, Wenz F, von Knebel-Doeberitz M and Reuschenbach M: Prognostic relevance of HPV infection and p16 overexpression in squamous cell anal cancer. Int $\mathrm{J}$ Radiat Oncol Biol Phys 93: 819-827, 2015.

21. Meulendijks D, Tomasoa NB, Dewit L, Smits PH, Bakker R, van Velthuysen ML, Rosenberg EH, Beijnen JH, Schellens JH and Cats A: HPV-negative squamous cell carcinoma of the anal canal is unresponsive to standard treatment and frequently carries disruptive mutations in TP53. Br J Cancer 112: 1358-1366, 2015.

22. Smaglo BG, Tesfaye A, Halfdanarson TR, Meyer JE, Wang J, Gatalica Z, Reddy S, Arguello D and Boland PM: Comprehensive multiplatform biomarker analysis of 199 anal squamous cell carcinomas. Oncotarget 6: 43594-43604, 2015.

23. De Roock W, Claes B, Bernasconi D, De Schutter J, Biesmans B, Fountzilas G, Kalogeras KT, Kotoula V, Papamichael D, Laurent-Puig P, et al: Effects of KRAS, BRAF, NRAS, and PIK3CA mutations on the efficacy of cetuximab plus chemotherapy in chemotherapy-refractory metastatic colorectal cancer: A retrospective consortium analysis. Lancet Oncol 11: 753-762, 2010.

24. Bidinotto LT, Véo CA, Loaiza EA, De França AP, Lorenzi AT, Rosa LA, De Oliveira CM, Levi JE, Scapulatempo-Neto C, Longatto-Filho A and Reis RM: Low mutation percentage of KRAS and BRAF genes in Brazilian anal tumors. Mol Med Rep 14: 3791-3797, 2016.

25. Scapulatempo-Neto C, Veo C, Fregnani JHTG, Lorenzi A, Mafra A, Melani AGF, Loaiza EAA, Rosa LAR, de Oliveira CM, Levi JE and Longatto-Filho A: Characterization of topoisomerase II $\alpha$ and minichromosome maintenance protein 2 expression in anal carcinoma. Oncol Lett 13: 1891-1898, 2017.

26. Martinho O, Campos M, Ribeiro G, Penna V, Curcelli EC, Olivieri MV, Morini S, Scapulatempo C, Abrahão-Machado LF and Reis RM: Raf kinase inhibitor protein expression and prognostic value in soft tissue sarcomas. Pathobiology 83: 41-46, 2016.

27. Matalon SA, Mamon HJ, Fuchs CS, Doyle LA, Tirumani SH, Ramaiya NH and Rosenthal MH: Anorectal cancer: Critical anatomic and staging distinctions that affect use of radiation therapy. Radiographics 35: 2090-2107, 2015.

28. Franklin RA, Giri S, Valasareddy P, Lands LT and Martin MG: Comparative survival of patients with anal adenocarcinoma, squamous cell carcinoma of the anus, and rectal adenocarcinoma. Clin Colorectal Cancer 15: 47-53, 2016.

29. Bilimoria KY, Bentrem DJ, Rock CE, Stewart AK, Ko CY and Halverson A: Outcomes and prognostic factors for squamous-cell carcinoma of the anal canal: Analysis of patients from the national cancer data base. Dis Colon Rectum 52: 624-631, 2009.

30. Vandamme D, Herrero A, Al-Mulla F and Kolch W: Regulation of the MAPK pathway by raf kinase inhibitory protein. Crit Rev Oncog 19: 405-415, 2014.

31. Fedchenko N and Reifenrath J: Different approaches for interpretation and reporting of immunohistochemistry analysis results in the bone tissue-a review. Diagn Pathol 9: 221, 2014.

32. Hu CJ, Zhou L, Zhang J, Huang $\mathrm{C}$ and Zhang GM: Immunohistochemical detection of Raf kinase inhibitor protein in normal cervical tissue and cervical cancer tissue. J Int Med Res 39: 229-237, 2011. 